\title{
Design and Implementation Supervisory Control and Data Acquisition (SCADA) of Filtration Process of Water Treatment Plant (WTP) by Using Raspberry PI
}

\author{
Sayidha Larasati ${ }^{1}$, Eki Ahmad Zaki Hamidi ${ }^{2}$, Mufid Ridlo Effendi ${ }^{3}$ \\ \{sayidhalarasati@gmail.com ${ }^{1}$, ekiahmadzaki@uinsgd.ac.id², mufid.ridlo@uinsgd.ac.id ${ }^{3}$ \} \\ Electrical Engineering Department, Science and Technology Faculty, UIN Sunan Gunung Djati \\ Bandung ${ }^{1,2,3}$.
}

\begin{abstract}
Water is a basic need important for humans. Raw water suitable for daily use, is not enough to just clean and clear presentation. But the quality also needs to be tested. The water quality be tested in Water Treatment Plant (WTP). Which one important step in WTP process is filtration. Filtration is instead to filter out suspended solids in water. To realize good water quality, must do check PH. Supervisory Control and Data Acquisition or SCADA is which one system can do that thing. SCADA system program among other is controlling, monitoring and data acquisition. Raspberry $\mathrm{Pi}$ is a mini computer which make SCADA system program in filtration process with the others component like a pump and Sensor SKU:SEN0161. the pump is applied to move water in filtration process and SKU:SEN0161 will checking $\mathrm{pH}$ water after filtration process. All components are controlled by Raspberry Pi. There are 4 samples of water used before entering the filtration with different $\mathrm{pH}$ values. There are 6.0, 6.2, 8.8 and 9.0. 4 samples were varied again with 3 variations volume of water, there are $1 \mathrm{~L}, 3 \mathrm{~L}$ and $5 \mathrm{~L}$ in certain time. The above water sample is fed into the filtration and when checking the $\mathrm{pH}$ value, the result is in accordance with the parameters which are between $6.5-8.5$. The results will be displayed and stored on web by Raspberry Pi.
\end{abstract}

Keywords: Filtration, Raspberry Pi, SCADA.

\section{Introduction}

Water is a component that plays an important role for the survival of all living things on this earth. Actually, almost two-thirds of the earth consists of water. It's just that most of it is salt water (sea water). Freshwater distribution is not always the same number between regions. So it is not a thing that is foreign to us if in an area the availability of water is so abundant, while in other areas lack of water. The water contained in the earth is called groundwater and what is found on the surface of the earth is called surface water. Surface water can be found in the form of rivers, seas, rain, lakes, etc. Because it is easy to dissolve other substances, the water is very easily contaminated by the substances it passes [1]. So that surface water cannot be consumed directly by residents. In order for water to be consumed, water must go through the Water Treatment Plant (WTP) process.

Water Treatment Plant (WTP) is an integrated system that functions to treat water from contaminated raw water quality to the desired water quality according to predetermined quality standards [2]. Generally, Processing water instalation is a system which combine process of 
coagulation, flocculation, sedimentation, filtration, disinfection, and completelly by controlling process and measurement that needed [3], one of which is filtration. The filtration process is to drain sedimentary water or raw water through sand. Filtration can be classified into fast sand filters (pressurized filters and open filters) and slow sand filters [4]. In order for the filtration process to be controlled, the SCADA system is applied in it. Supervisory Control and Data Acquisition (SCADA) is a system that can carry out supervision, control and data acquisition of a plant. Along with the rapid development of computers in the last few decades, computers have become an important component in a modern SCADA system [5]. This system will be applied in the process of filtration of the Water Treatment Plant. This system will facilitate the filtration process, because the system will control and supervise the process without direct human intervention (automatic). And this filtration process can be monitored in long distances without having to go to the field at any time to monitor the filtration process.

There is one system similar to SCADA, namely DCS. Distributed Control System (DCS) is a system that distributes various functions that are used to control various process variables and process operation units into a control centered on a control room with various functions of control, monitoring and optimization. The integrated DCS system is intended to control a continuous or batch-oriented manufacturing process, such as oil refining, petrochemical, central station and paper making [6]. In the way it works, DCS and SCADA are almost the same, they are doing control and monitoring. But there are some things that make these two systems different. DCS communicates with operators with limited range or can be accessed by certain operators within a certain distance. While SCADA can be accessed by operators at any time without distance restrictions. And SCADA has data acquisition, which means the system has the latest data and previous data in a process while DCS only monitors. DCS is a closed loop control which means that the output affects the plant (feedback) while SCADA does open loop control which means the output does not affect the plant. DCS requires communication systems with high speed and reliability while SCADA requires a low speed communication system [6]. From the above comparison, the SCADA system is more practical than DCS. However, SCADA and DCS have their own advantages and disadvantages. Over time SCADA has become more sophisticated, practical, inexpensive and its general use can be applied to small-scale (prototype) and industrial processes. To implement a SCADA system in the filtration process, it requires a Remote Terminal Unit (RTU) or a tool to make it happen.

The Raspberry Pi was chosen to act as the master controller and data logger (the process of controlling, collecting and recording data from the sensor for archiving or analytical purposes). This option allows the user interface or the relationship between the user and the operating system. Raspberry Pi uses a phyton language that allows users to enter run times and the number of cycles that must be repeated while also displaying updated system information or what is called monitoring. The final system designed is log data (collection and recording of data) that is produced which contains data / $\mathrm{pH}$ values that are correct in accordance with the expected and observed [7]. Raspberry Pi can control, monitor and acquisitio data. The Raspberry Pi can control indicators and actuators in the filtration process by controlling the pump which will carry out the filtration process and activate the water $\mathrm{pH}$ detection sensor. The $\mathrm{pH}$ value of water obtained is then displayed on the web.

\section{Design and Implementation}

\subsection{Hardware Design}


After looking at the SCADA system design image in the filtration process, the next is hardware design. Based on the analysis of requirements, to make the SCADA system in the filtration process there are several tools and materials needed, including:

1. The Raspberry Pi is used to activate sensor and relay functions. Also set the web display.

2. Laptops / Smartphones are used to view the final results and data on acquisition of $\mathrm{pH}$ values over the web remotely

3. 3. Sensor SKU: SEN0161 is used to check the $\mathrm{pH}$ value of water

4. 4. Relays and pumps are used to control the entry and discharge of water in the filtration process

The system design of supervisory control and data acqusition in the web-based filtration process is shown in Figure 1.

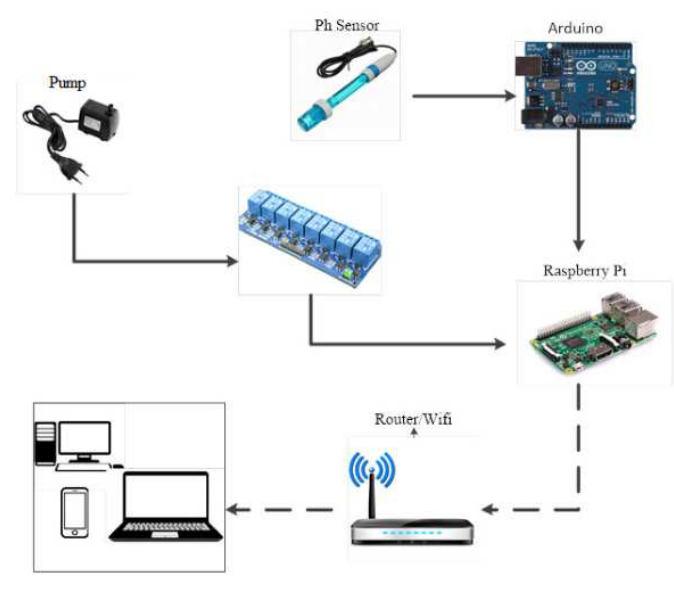

Figure 1. Design of Supervisory Control and Data Acquisition System in Web-Based Filtration Process

The $\mathrm{pH}$ sensor works to check the $\mathrm{pH}$ level of water based on the number of electrons in the water sample. The more electrons in water, the more acidic water will be.

After making a SCADA system, miniature filtration is then made. Miniature filtration is made to filter out water that has an unstable $\mathrm{pH}$ level, as shown in Figure 2.

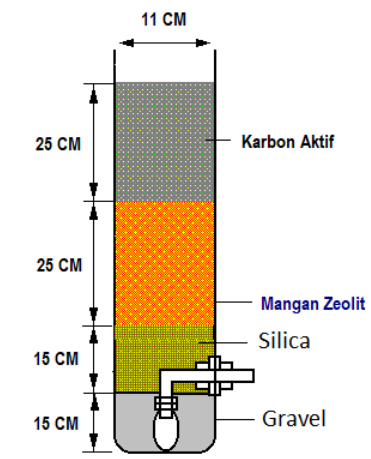


Figure 2. Miniature Filtration

The filtration process uses 3 water containers, 1 filtration and 2 pumps. The composition of the filtration process is shown in Figure 3.

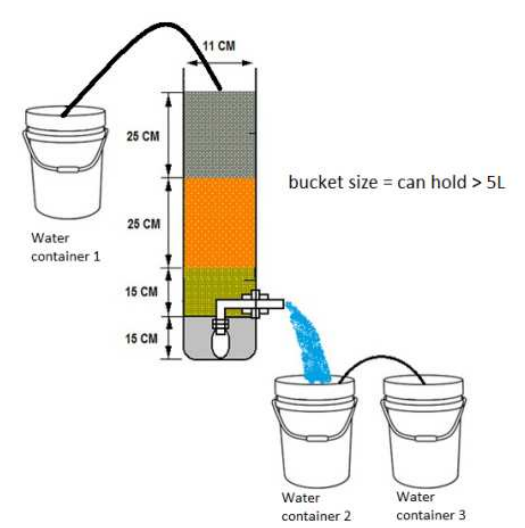

Figure 3. Filtration Process Arrangement

Water container 1 to contain raw water to be filtered. Water container 2 to hold filtrated water. Water container 3 to hold water that has been detected by $\mathrm{pH}$. Sensor SKU: SEN0161 is installed in container 2 and for pumps installed in water container 1 and water container 2 .

\subsection{Software Design}

SCADA system software design in the filtration process uses the programming language $\mathrm{C}$, python and html. Here are some software used in this research:

1. Arduino IDE is used to upload programs to Arduino devices to activate the $\mathrm{pH}$ sensor function.

2. Python is used to send $\mathrm{pH}$ water output to the database and set the relay function.

3. MySQL is a database server, used to create an application server that will then store the output $\mathrm{pH}$ value.

4. Atom, used to create web with html language.

5. VNC, used to control other computers through an internet connection (long distance).

The web system supervisory control algorithm and data acqusition in the filtration process are shown in Figure 4. 


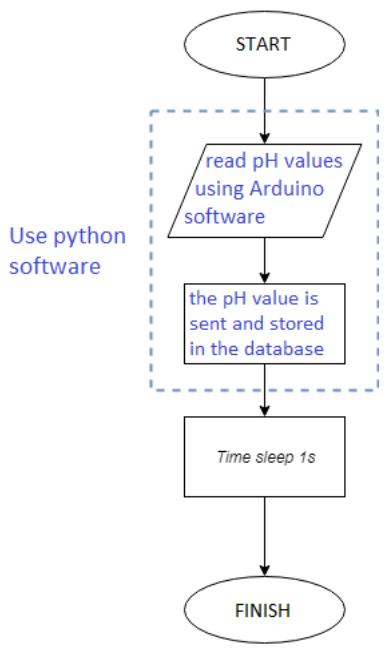

Figure 4. Algorithm Making web System Supervisory Control and Data Acquisition in Filtration Process

\section{Result}

System testing is a test to determine the performance of the RTU (Remote Terminal Unit) with sensors and actuators. Then it is associated with MTU (Master Terminal Unit). This test is done by simulating the filtration process using the SCADA system. To activate the indicator on this system, do the testing by entering water into the filtration with different $\mathrm{pH}$ values outside the (standard) parameters. Then each $\mathrm{pH}$ value is varied again in the volume of water. This test is conducted to determine the performance of the SCADA system at the filtration stage only. The success of the test is the $\mathrm{pH}$ value of the water after filtration according to the parameters. Namely ranging from 6.5 to 8.5 . The tool designed is still relatively simple as shown in Figure 5.

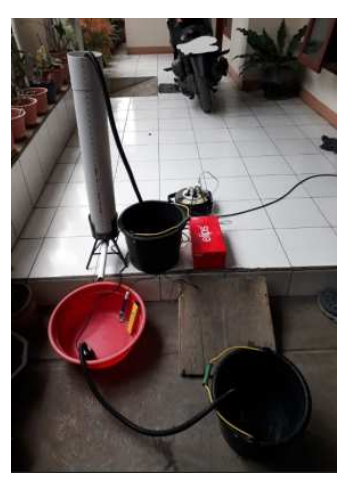

Figure 5. Filtration Simulation 


\subsection{Testing of Sensors and Actuators}

To find out the performance of the $\mathrm{pH}$ sensor, then in this test 4 variations in the $\mathrm{pH}$ value of the water were carried out before entering filtration (input). This variation of input is the $\mathrm{pH}$ value of the water outside the parameter boundary. The limit of water parameters is $6.5-8.5$. So that the input values of $\mathrm{pH} 6.0$ and 6.2 for acidic water types, 9.0 and 8.8 for alkaline water types were obtained.

In addition, this test is not only done based on variations in input $\mathrm{pH}$ values only. Each input of the $\mathrm{pH}$ value is given 3 variations of the same volume of water $(\mathrm{V})$ including as many as $1 \mathrm{~L}, 3 \mathrm{~L}$ and $5 \mathrm{~L}$ in a certain time $(\mathrm{t})$. The amount of water $(\mathrm{V})$ through filtration per unit time $(\mathrm{t})$, produces a water discharge $(\mathrm{Q})$.

Q1 is the value of water discharge after passing through filtration with a volume of water of $1 \mathrm{~L} . \mathrm{Q} 2$ is the value of water discharge after passing through filtration with a volume of water of $2 \mathrm{~L}$. And Q3 is the value of water discharge after passing filtration with volume of water $3 \mathrm{~L}$. After finding the value of water discharge, then check the $\mathrm{pH}$ value of water after passing through filtration (output).

Checking the $\mathrm{pH}$ value of water requires a stable time for 1 minute. After 1 minute has elapsed, the actual $\mathrm{pH}$ value of the $\mathrm{pH}$ sensor comes out. The $\mathrm{pH}$ value after filtration for water samples 6.0 is shown in Table 1.

Table 1. PH Value After Filtration for Water Samples with $\mathrm{pH}$ Value 6.0

\begin{tabular}{cccc}
\hline $\begin{array}{c}\text { Seconds to } \\
-\end{array}$ & $\begin{array}{c}\text { PH Value } \\
\text { of Output } \\
\text { Q1 }\end{array}$ & $\begin{array}{c}\text { PH Value } \\
\text { of Output } \\
\text { Q2 }\end{array}$ & $\begin{array}{c}\text { PH Value } \\
\text { of Output } \\
\text { Q3 }\end{array}$ \\
\hline 1 & 0 & 0 & 0 \\
2 & 0,16 & 0,16 & 0,16 \\
3 & 0,31 & 0,31 & 0,31 \\
4 & 0,47 & 0,47 & 0,47 \\
5 & 0,62 & 0,62 & 0,62 \\
6 & 0,77 & 0,77 & 0,77 \\
7 & 0,93 & 0,93 & 0,93 \\
8 & 1,08 & 1,08 & 1,08 \\
$\ldots$. & $\ldots \ldots$ & $\ldots$. & $\ldots$. \\
$\ldots$. & $\ldots .$. & $\ldots$. & $\ldots$ \\
60 & 6,97 & 6,87 & 6,93 \\
61 & 6,97 & 6,87 & 6,93 \\
62 & 6,97 & 6,87 & 6,93 \\
63 & 6,97 & 6,87 & 6,93 \\
64 & 6,97 & 6,87 & 6,93 \\
\hline
\end{tabular}

Furthermore, the pH value after filtration for Water Samples 6.2 is shown in Table 2.

Table 2. PH Value After Filtration for Water Samples with $\mathrm{pH}$ Value 6.2 


\begin{tabular}{cccc}
\hline $\begin{array}{c}\text { Seconds to } \\
-\end{array}$ & $\begin{array}{c}\text { PH Value } \\
\text { of Output } \\
\text { Q1 }\end{array}$ & $\begin{array}{c}\text { PH Value } \\
\text { of Output } \\
\text { Q2 }\end{array}$ & $\begin{array}{c}\text { PH Value } \\
\text { of Output } \\
\text { Q3 }\end{array}$ \\
\hline 1 & 0 & 0 & 0 \\
2 & 0,16 & 0,16 & 0,16 \\
3 & 0,31 & 0,31 & 0,31 \\
4 & 0,47 & 0,47 & 0,47 \\
5 & 0,62 & 0,62 & 0,62 \\
6 & 0,77 & 0,77 & 0,77 \\
7 & 0,93 & 0,93 & 0,93 \\
8 & 1,08 & 1,08 & 1,08 \\
$\ldots$ & $\ldots \ldots$ & $\ldots$. & $\ldots$. \\
$\ldots$. & $\ldots$. & $\ldots$. & $\ldots$. \\
60 & 6,99 & 7,01 & 7,01 \\
61 & 6,99 & 7,01 & 7,01 \\
62 & 6,99 & 7,01 & 7,01 \\
63 & 6,99 & 7,01 & 7,01 \\
64 & 6,99 & 7,01 & 7,01 \\
\hline
\end{tabular}

Next the $\mathrm{pH}$ value after filtration for Water Sample 9.0 is shown in Table 3.

Table 1. PH Value After Filtration for Water Samples with $\mathrm{pH}$ Value 9.0

\begin{tabular}{cccc}
\hline $\begin{array}{c}\text { Seconds to } \\
-\end{array}$ & $\begin{array}{c}\text { PH Value } \\
\text { of Output } \\
\text { Q1 }\end{array}$ & $\begin{array}{c}\text { PH Value } \\
\text { of Output } \\
\text { Q2 }\end{array}$ & $\begin{array}{c}\text { PH Value } \\
\text { of Output } \\
\text { Q3 }\end{array}$ \\
\hline 1 & 0 & 0 & 0 \\
2 & 0,16 & 0,16 & 0,16 \\
3 & 0,31 & 0,31 & 0,31 \\
4 & 0,47 & 0,47 & 0,47 \\
5 & 0,62 & 0,62 & 0,62 \\
6 & 0,77 & 0,77 & 0,77 \\
7 & 0,93 & 0,93 & 0,93 \\
8 & 1,08 & 1,08 & 1,08 \\
$\ldots$. & $\ldots$. & $\ldots .$. & $\ldots$. \\
$\ldots$. & $\ldots$. & $\ldots$. & $\ldots$ \\
60 & 7,33 & 7,42 & 7,58 \\
61 & 7,33 & 7,42 & 7,58 \\
62 & 7,33 & 7,42 & 7,58 \\
63 & 7,33 & 7,42 & 7,58 \\
64 & 7,33 & 7,42 & 7,58 \\
\hline
\end{tabular}

The last $\mathrm{pH}$ value after filtration for Water Sample 8.8 is shown in Table 4.

Table 2. PH Value After Filtration for Water Samples with $\mathrm{pH}$ Value 8.8 


\begin{tabular}{cccc}
\hline $\begin{array}{c}\text { Seconds to } \\
-\end{array}$ & $\begin{array}{c}\text { PH Value } \\
\text { of Output } \\
\text { Q1 }\end{array}$ & $\begin{array}{c}\text { PH Value } \\
\text { of Output } \\
\text { Q2 }\end{array}$ & $\begin{array}{c}\text { PH Value } \\
\text { of Output } \\
\text { Q3 }\end{array}$ \\
\hline 1 & 0 & 0 & 0 \\
2 & 0,16 & 0,16 & 0,16 \\
3 & 0,31 & 0,31 & 0,31 \\
4 & 0,47 & 0,47 & 0,47 \\
& & & \\
5 & 0,62 & 0,62 & 0,62 \\
6 & 0,77 & 0,77 & 0,77 \\
7 & 0,93 & 0,93 & 0,93 \\
8 & 1,08 & 1,08 & 1,08 \\
$\ldots$. & $\ldots$. & $\ldots$. & $\ldots$. \\
$\ldots$. & $\ldots .$. & $\ldots$. & $\ldots$ \\
60 & 7,6 & 7,4 & 7,58 \\
61 & 7,6 & 7,4 & 7,58 \\
62 & 7,6 & 7,4 & 7,58 \\
63 & 7,6 & 7,4 & 7,58 \\
64 & 7,6 & 7,4 & 7,58 \\
\hline
\end{tabular}

\subsection{MTU Test (Master Terminal Unit)}

In testing MTU (Master Terminal Unit) this is done on the Raspberry pi. MTU is part of the SCADA system for storing sensor data. Then the data will be used for the monitoring process and data acquisition. Following are the stages of the MTU testing.

1. Communication System Testing

Communication system testing is done by connecting between the RTU (Raspberry pi) and MTU (laptops, smartphones, etc.). Communication will be connected if the RTU with the MTU is in 1 router as shown in Figure 6.

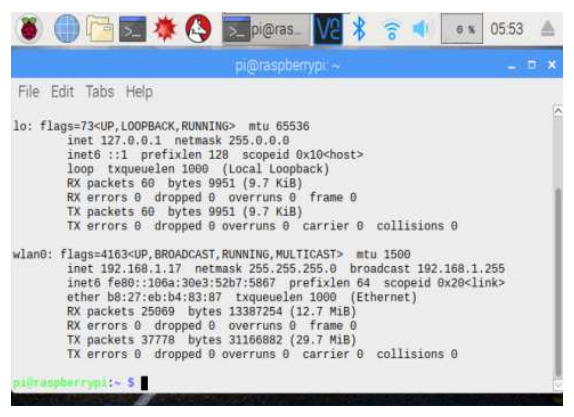

Figure 6. Raspberry Pi IP Number

2. Database 
Database testing is done by entering the Raspberry Pi IP into the browser. The database server used is MySQL. This database serves as a store of sensor data information as in Figure 7.

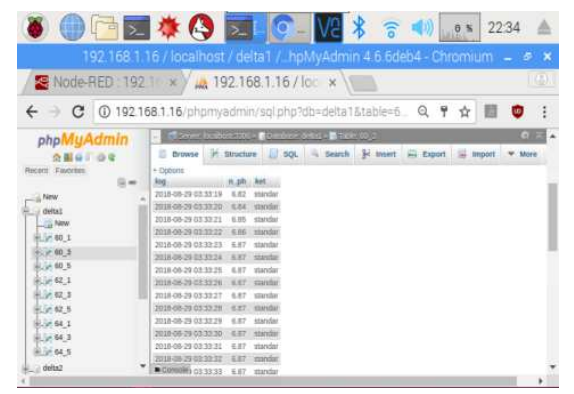

Figure 7. Data stored in Database

\section{Web Display}

Web display is a process of interface between RTU and MTU. Web display is not only on other computers or laptops, but can be applied to other devices such as smartphones shown in Figure 8 .

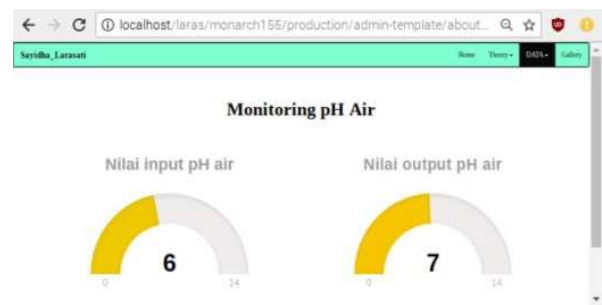

Figure 8. Monitoring the Filtration Process with Acidic Water Samples using a Laptop

\section{Conclution}

The conclusion of the Supervisory Control and Data Acquisition System in the Water Treatment Plant filtration process using the Web-based Raspberry Pi 3 is as follows:

1. Raspberry Pi as a Master Terminal Unit (MTU) system that functions to control (controlling) input and output, monitoring (monitoring) and data storage (data acquisition) on the system. Starting from controlling what Raspberries do to input and output. The input in question is a $\mathrm{pH}$ sensor. And the output is a relay and pump. In the fitration process, everything operates according to their respective functions. The input or $\mathrm{pH}$ sensor works to check the $\mathrm{pH}$ value which is then sent to Raspberry Pi using python. Output or relay and pump work to do the filtration process using python too. Starting from putting water into filtration and moving water to a reservoir. Then the Raspberry Pi sends sensor data to the database so that data can be displayed on the web. And the data is successfully displayed on the web. The information above states that the SCADA system in the Water Treatment Plant filter process using the web-based Raspberry Pi has been running well. 
2. Performance in the filtration process works as expected. When the filtration process in acidic water, the water produced is in accordance with the water parameters of $6.5-8.5$. Likewise with alkaline water. The water produced is in accordance with the water parameters. When acidic water enters filtration, water that has been of low value from the parameters increases according to the water standard. Whereas when alkaline water enters the filtration, the water that has been of high value from the parameters falls down to adjust to the water standard. The $\mathrm{pH}$ value of the water can be seen from the $\mathrm{pH}$ sensor. However, the $\mathrm{pH}$ value cannot directly or spontaneously state that the value is correct (not constant). The $\mathrm{pH}$ sensor has a response time of 1 minute so that the $\mathrm{pH}$ sensor has the value stated correctly or the value is constant

3. Performance of the monitoring system and data acquisition using the web as expected. Sensor data from the database has been successfully displayed on the web. In addition, web displays can be displayed on other devices such as computers, laptops, smartphones, etc

\section{Acknowledgements}

In this research, we would like to thank to Wahyudin Darmalaksana Head of Pusat Penelitian dan Penerbitan LP2M UIN (Universitas Islam Negeri) Sunan Gunung Djati Bandung Indonesia, who has been supported.

\section{References}

[1] D. Susanto, T. U. Kalsum, and Y. S. H, “Alat Penyaringan Air Kotor Menjadi Air Bersih,” J. Media Infotama, vol. 10, no. 2, pp. 142-150, 2014.

[2] Iqbal Shalahuddin, "Water Treatment Plant = Instalasi Pengolahan Air | IQBAL-SHALAHUDDIN." [Online]. Available: https://iqshalahuddin.wordpress.com/2016/04/13/water-treatment-system-vs-watertreatment-plant/. [Accessed: 28-Aug-2019].

[3] E. Ahmad Zaki Hamidi, M. Ridlo Effendi, and H. Ash Shiddiq, "Design and Implementation Supervisory Control and Data Acquisition (SCADA) of Sedimentation Process of Water Treatment Plant (WTP) by Using Raspberry PI 3 B," Proceeding 2018 4th Int. Conf. Wirel. Telemat. ICWT 2018, pp. 17, 2018.

[4] N. F. Arifiani and M. Hadiwidodo, "Evaluasi Desain Instalasi Pengolahan Air Pdam Ibu Kota,” J. PRESIPITASI, vol. 3, no. 2, pp. 78-85, 2007.

[5] A. Fahluvi, "Universitas indonesia aplikasi scada,” F. Tek. P. Stud. T. Elektro, p. pp.115, 2010.

[6] E. Knapp, Industrial network security: Securing critical infrastructure networks for smart grid, scada, and other industrial control systems. 2011.

[7] T. Haines and F. Joyce, "Raspberry Pi Human Machine Interface and Control System for an Electromagnet Water Filter,” Proc. Annu. Mont. Tech Electr. Gen. Eng. Symp., vol. 19, p. 47, 2017. 